The successor to the journal Music Review, Nineteenth-Century Music Review aims to locate music within the widest possible framework of intellectual activity pertaining to the long nineteenth century (c.1789-1914). It particularly welcomes interdisciplinary scholarship that explores music within the context of other artistic and scientific discourses. Articles with fine visual or iconographic content are encouraged, as are those rich in musically illustrative material. Articles accepted for publication will reflect a diversity of critical viewpoints.

\title{
Contents of Volume 3, Issue 2
}

Articles

Susan Youens

Allan W. Atlas

Graham Hunt

Jonathan Del Mar

John Hughes

Natasha Loges
'Pure' Song: 'Du bist wie eine Blume' and the Heine Juggernaut

The Victorian Concertina: Some Issues Relating to Performance

Of Refrains, Fairy-tales and Compositional Hesitation: Act II of Wagner's Siegfried Revisited

More about Beethoven in Steiner's Shop: Publishers' Corrections to the First Edition of the Quartet in F Minor, op. 95. A Tribute to Alan Tyson

'The Exile's Harp': Tennyson's Lost World of Music

Exoticism, Artifice and the Supernatural in the Brahmsian Lied

Book Reviews

CD Reviews

Score Reviews

Published in association with the Centre for Nineteenth-Century Music, Durham University, UK

Cover illustration: The reed pan of an English concertina (48-button treble), Wheatstone No. 6760, 1855.

\section{ASHGATE}

Ashgate Publishing Limited Gower House, Croft Road

Aldershot, Hampshire

GU113HR, England

www.ashgate.com

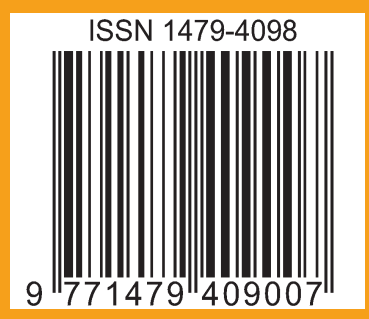

